\title{
Diseases And Pests Associated to Tomato Cultivation in The Locality of Daloa (Côte d'Ivoire)
}

Tonessia Dolou Charlotte*, Soumahin Eric Francis, Boye Mambé Auguste Denise, Niangoran Yate Atse Toussaint, Djabla Jean Marc, Zoh Olivia Dominique et Kouadio Yatty Justin

Laboratoire d'Amélioration de la production Agricole, UFR-Agroforesterie, Université Jean Lorougnon Guédé BP 150 Daloa (Côte d'Ivoire)

dolouc@yahoo.fr

\begin{abstract}
This study aims at identifying the major tomato pests and diseases in the locality of Daloa. To achieve this goal, surveys were conducted among tomato farmers in the city, the outskirts and the villages of Daloa. They consisted in questioning farmers about their identity, the cropping practices and the problems encountered in the practice of tomato cultivation. Then another step consisted in monitoring tomato farms for observing diseases and pests associated to tomato. The results of the study showed that tomato cultivation is concentrated in rural areas and is carried out by men with a very low level of education. The most cultivated varieties are petromech and cobra because of their resistance to certain pests. Several tomato diseases have been identified, however the most significant were seedling damping-off (Pythium sp, Fusarium sp, Rhizoctonia solani), plant wilting (Fusarium oxyporum and Ralstonia solanacerum), fruit anthracnose (Colletotrichum $s p$.), apical necrosis and root-knot nematode (Meloidogyne sp.). The main pests observed on tomato in the locality were Helicoverpa armigera (Lepidoptera), Bemisia tabaci (Homoptera), Dysdercus sp. (Hemiptera). This study provides a pathway from which further studies including mapping the different diseases could be conducted so as to better monitor and protect tomato cultivation.
\end{abstract}

Indexing terms/Keywords: Tomato pests; Tomato diseases; tomato farmers; rural areas of Daloa; diseases mapping.

\section{Subject Classification: Plant Pathology}

Type (Method/Approach): Field experiment

\section{Introduction}

Tomato (Solanum lycopersicum L.) belongs to the Solanaceae family just like eggplant, pepper, potato. It is one of the most consumed foods because of its high content in nutrients such as vitamins and minerals that are important for human well-balanced diets. Moreover, tomato is an essential dietary component; it contains a high level of lycopene, an antioxidant which might reduce the risks associated with several types of cancer (Srinivasan, 2010). In Côte d'Ivoire, tomato cultivation is practiced in many areas including the locality of Daloa (Doumbouya et al., 2010). Its production and sale represent, for many smallholders of this city located in west central Côte d'Ivoire, a lucrative activity in rural, urban and peri-urban areas. However local and even domestic tomato yield covers less than 60 percent of the needs in Côte d'Ivoire. Indeed, the Ivorian annual yield fluctuates between 22000 and $35000 \mathrm{t}$ for an estimated need of more than $100000 \mathrm{t}$ (Fondio et al., 2013). The deficit, which is mainly linked to the local difficulties of tomato cultivation, is filled by high import from the countries of the sub-region.

Among the several biotic and abiotic factors that significantly hamper tomato production and maintain its yield at a very low level (Yeboue et al., 2002, Soro et al., 2008), diseases and insects are in a prominent position. The average losses estimated by the action of pests represent about $15 \%$ of the agricultural production (Doumbouya et al., 2010). However, in some localities and under certain local cultivation conditions, yield losses of up to $95 \%$ have been reported (Nguessan el al., 2012). The extent of yield losses depends on the intensity of attacks by diseases and pests. Thus, crop and fruit losses due to a particular 
disease vary from one place to another due to the existence of different pathogen races, biotypes, or strains (Sastry and Hegde, 1989).

Tomato plants are infected by a plethora of diseases (Jones, 1991) and to date it is difficult to set up a general method for their detection and characterization. Despite this, the advent of molecular biology techniques has made it possible to identify new pathogens and even to characterize those already identified. Using these modern tools, the locality of Daloa has been identified as hosting one of the most virulent strains of Ralstonia solanacerum, the agent responsible for tomato plant wilt (Nguessan el al., 2012). However, the rise of modern tools for the detection and characterization of pathogens (serological, but above all molecular) should not overshadow the true nature of plant disease diagnosis, which is a science that gives pride of place to hands-on knowledge and symptomatology (Blancard et al, 2003). Thus, understanding of tomato diseases and pests will help ensure effective biological monitoring of cultivated territories so as to avoid the introduction of new parasites and / or their dispersal (Semal and Lepoivre, 2003). Unfortunately, the list of tomato pests is not drawn up in Department of the Daloa. However, the preliminary step to succeed in protecting this crop is the understanding of the diseases and pests that limit its yield. It is in this perspective that this work has been conducted. It aims at taking inventory of the major tomato diseases and pests in the locality of Daloa. We thus hope to provide a document on which future work on protection and health monitoring of this vegetable fruit in Daloa can be based.

\section{Material and Method}

\section{Presentation of the study area}

The farms in which the experiments were carried out were located in the city and the outskirts of Daloa $\left(6.8883^{\circ} \mathrm{N}, 6.4397^{\circ} \mathrm{W}\right)$ in West Central Côte d'Ivoire. The climate in the region of Daloa is humid tropical with an average temperature of $27.75^{\circ} \mathrm{C}$. The average rainfall recorded over the last ten years in the region was $1302.23 \mathrm{~mm}$ of rain / year and the climate has two rainy seasons and two dry seasons. On average, the hottest months are January, February, March, April, May, November and December. September is the rainiest month. The work ran from December 2016 to November 2017 so as to cover all the seasons.

\section{Survey among farmers}

The methodology initially consisted in conducting a survey among tomato farmers in the area of Daloa. Thus, from an exploration in the region of Daloa, a list of several tomato production sites was drawn up. The surveys were conducted in the city and outskirts of Daloa, in the production sites of Tazibouo, Gbeulville, Lobia, Issia Corridor, Man Corridor, Huberson as well as in the rural areas of Sikaboutou, Yaokro, Gonaté and Mahounou. A first study consisted in interviewing producers directly from a previously established questionnaire form. The questions focused on the identity of the producer, the cropping practices and the problems encountered in the practice of tomato cultivation. Then another step consisted in monitoring the farms for taking inventory of tomato diseases and pests

\section{Inventory of pests and diseases in farms}

Observations of tomato pests and diseases were made using the systematic excavation method and the direct plot observation technique, respectively. The aim was to observe very early in the morning between 6:30 and 10:00 on a weekly basis and to describe all diseases and pests appearing on tomatoes. In this respect, the direct observations technique (with the eyes) on the different parts of plants (leaves, stems, roots if necessary) was used. The anomalies observed during such observations were described in considerable detail on an observation sheet and were accompanied by pictures taken with a Finepix $\mathbf{S}$ digital camera to illustrate the description. In the formal identification of certain fungal pathogens associated with certain symptoms observed in the farms, samples were taken from the diseased organs. The samples were transported to the laboratory of plant pathology of the University Jean Lorougnon Guédé of Daloa for their culture and 
identification (Tonessia et al., 2018). Similarly, some insects were captured and stored in ethanol diluted to $70 \%$ for identification in the laboratory.

Data analysis was based on statistical methods and was used to identify trends expressed in percentages using EXCEL spreadsheet. This software made it possible to produce descriptive statistics (frequencies and averages). Insects collected or observed were identified using methodology of Hugh et al. (2015).

\section{Results}

\section{Characteristics of tomato famers and production practices in the locality of Daloa}

The total number of respondents in the survey was 31 and the results of the survey among them are shown in Table 1 . About $80 \%$ of them produced tomatoes in rural and peri-urban areas while $20 \%$ were located in the city. The most cultivated variety was Cobra 26 , however $40 \%$ of the respondents used the Pectomech variety as combination in the farms. Tomato cultivation is carried out by smallholders because $94 \%$ of them have less than $1 \mathrm{ha}$. Overall, the plots of land were in lease mode. The labor used by the producers was essentially family (100\%). Fifteen percent (15\%) of the respondents applied NPK as fertilizer followed by urea while $6 \%$ applied NPK only. The majority of respondents (69\%) said they used chicken manure because of its availability and lower cost. Ten percent (10\%) of respondents mainly located in the city of Daloa bought compost or made it themselves. All respondents said they proceeded by setting up a tomato nursery before transplanting. It should be noted that $2 \%$ of respondents grew tomatoes hydroponically in the city of Daloa.

Table 1: Characteristics of tomato farms in the locality of Daloa.

\begin{tabular}{lll}
\hline Characteristics & & Percentage (\%) \\
\hline Producers & Men & $\mathbf{9 4 \%}$ \\
& Women & $6 \%$ \\
\hline \multirow{2}{*}{ Varieties } & Cobra 26 & $\mathbf{1 0 0 \%}$ \\
& Pectomech & $40 \%$ \\
\hline \multirow{2}{*}{ Surface area } & & \\
(m2) & {$[1000,10000]$} & $94 \%$ \\
& $>10000$ & $6 \%$ \\
\hline \multirow{2}{*}{ Fertilization } & & \\
& NPK/UREE & $15 \%$ \\
& NPK & $\mathbf{6 \%}$ \\
& Chicken Manure & $69 \%$ \\
\hline Cultivation method & Compost & $10 \%$ \\
\hline & Nurseries & $\mathbf{1 0 0 \%}$ \\
& & $98 \%$ \\
& On-soil & $2 \%$ \\
& Hydroponic & \\
\hline
\end{tabular}




\section{Diseases associated to Tomato production in the locality of Daloa}

Through the field survey many diseases were found on all organs of the tomato plants (root, collar, stem, leaves and fruit) (Table 2). Such diseases were observed in tomato nurseries as well as in full on-soil or hydroponic cultivation (Figure 2).

Table 2. Main diseases of tomato grown in Daloa.

\begin{tabular}{llll}
\hline Diseases & Symptoms & $\begin{array}{l}\text { Target } \\
\text { organ }\end{array}$ & Causative agent \\
\hline $\begin{array}{l}\text { Seedling } \\
\text { damping-off }\end{array}$ & $\begin{array}{l}\text { Wet brown or white rot elongated from the } \\
\text { collar to the stem }\end{array}$ & $\begin{array}{l}\text { Root, collar } \\
\text { (nursery) }\end{array}$ & $\begin{array}{l}\text { Pythium sp, Fusarium } s p, \\
\text { Rhizoctonia solani }\end{array}$ \\
\end{tabular}

Fusarium wilt Onset, at the collar, of brown necrosis elongated

Collar, stem

Fusarium oxyporum and dry on one side, then went up towards the stem and ended with a complete desiccation of the plant.

Bacterial wilt Foliage wilting occurs during fruiting and fruit Leaf, full Ralstonia solanacerum ripening; this symptom is possibly followed by plant the collapse and death of infected plants

\begin{tabular}{|c|c|c|c|}
\hline Alternariose & $\begin{array}{l}\text { Infected plants showed black spots on the stem } \\
\text { and on the branches, some of which were zoned } \\
\text { with a more or less bright yellow center. Such } \\
\text { spots eventually become necrotic }\end{array}$ & Stem, leaf & Altemaria sp. \\
\hline Anthracnose & $\begin{array}{l}\text { The most visible symptoms appear on ripe fruits. } \\
\text { Small, round, depressed spots first appear and } \\
\text { gradually enlarge to } 20 \mathrm{~mm} \text { in diameter }\end{array}$ & Fruit, leaf & Colletotrichum sp \\
\hline Fruit soft rot & $\begin{array}{l}\text { The whole fruit fills with a } \\
\text { viscous mass, waterlogged and soft, protected } \\
\text { by a thin outer epidermis }\end{array}$ & Fruit & Erwiinia sp. \\
\hline $\begin{array}{ll}\text { Leaf } & \text { spot } \\
\text { disease } & \end{array}$ & $\begin{array}{l}\text { The upper surface of tomato leaves gradually } \\
\text { fades }\end{array}$ & Leaf & Pseudocercospora sp. \\
\hline Mildew & $\begin{array}{l}\text { On tomato leaves, spots develop from leaf tip or } \\
\text { margin. Such spots have an oily appearance with } \\
\text { a pale or brown color. On the underside of the } \\
\text { leaf, a white felting develops. Sometimes we can } \\
\text { notice the presence of brown spots on stems } \\
\text { and petioles }\end{array}$ & Feuille, tige & phytophthora infestans \\
\hline $\begin{array}{l}\text { Sclerotinia } \\
\text { disease }\end{array}$ & $\begin{array}{l}\text { In young plants, infection occurs on the } \\
\text { cotyledons. The lesions are oily at first, although } \\
\text { the rotten area remains fairly firm. Tissues } \\
\text { affected fades and there is invariably a prolific }\end{array}$ & $\begin{array}{l}\text { Collar, stem, } \\
\text { fruit }\end{array}$ & Sclerotinia sp \\
\hline
\end{tabular}




\begin{tabular}{|c|c|c|c|}
\hline $\begin{array}{l}\text { (white rot, } \\
\text { Sclerotinia } \\
\text { rot) }\end{array}$ & $\begin{array}{l}\text { growth of snow white fungal mycelium on the } \\
\text { stem }\end{array}$ & & \\
\hline Leaf curl & $\begin{array}{l}\text { The edge of the leaves wraps up and inwards, to } \\
\text { such an extent that the } \\
\text { leaves seem tubular }\end{array}$ & Leaf & Non-parasitic disease \\
\hline Radial Slots & $\begin{array}{l}\text { The radial slots cover the fruit from the } \\
\text { peduncle area. As the fruit grows, such slots } \\
\text { become deeper and expose the flesh of the fruit }\end{array}$ & fruit & Non-parasitic disease \\
\hline $\begin{array}{l}\text { Apical } \\
\text { necrosis }\end{array}$ & $\begin{array}{l}\text { Pale brown areas appear at the stylar scar of the } \\
\text { fruit, but sometimes also at the sides. The areas } \\
\text { become darker, and a black and depressed } \\
\text { tissue area forms and sometimes affects up to } \\
\text { half of the fruit. }\end{array}$ & fruit & Non-parasitic disease \\
\hline $\begin{array}{l}\text { Diseases due } \\
\text { to } \\
\text { Nématodes }\end{array}$ & $\begin{array}{l}\text { Infected plants are stunted and chlorotic and } \\
\text { undergo early senescence. The number and size } \\
\text { of fruits are reduced. }\end{array}$ & $\begin{array}{l}\text { Root and } \\
\text { collar }\end{array}$ & $\begin{array}{l}\text { Meloidogyne sp. } \\
\text { Pratylenchus sp }\end{array}$ \\
\hline
\end{tabular}

\section{Pests associated to tomato plants in the locality of Daloa}

Several insects were observed on tomato during the observation period from May to November 2017 (Figure 1). The most important ones by the damage caused were the species Helicoverpa armigera (Lepidoptera). This caterpillar attacked all parts of the tomato including leaves, flowers and fruits (Figure $1 \mathrm{~L}$ and $1 \mathrm{M}$ ). A strong infestation of this caterpillar has been noticed on hydroponic tomatoes. It's devastating effect on fruits resulted in hollows on tomatoes which went rotten thereafter. It was followed by piercing-sucking insects Bemisia tabaci (Homoptera) and Dysdercus sp. (Hemiptera) that pierce the plant tissues of the various organs of the tomato plant for feeding on its sap. As for the chewing insect Zenocerus variegatus (Orthoptera), it eats the leaves and flowers of the tomato plant. 

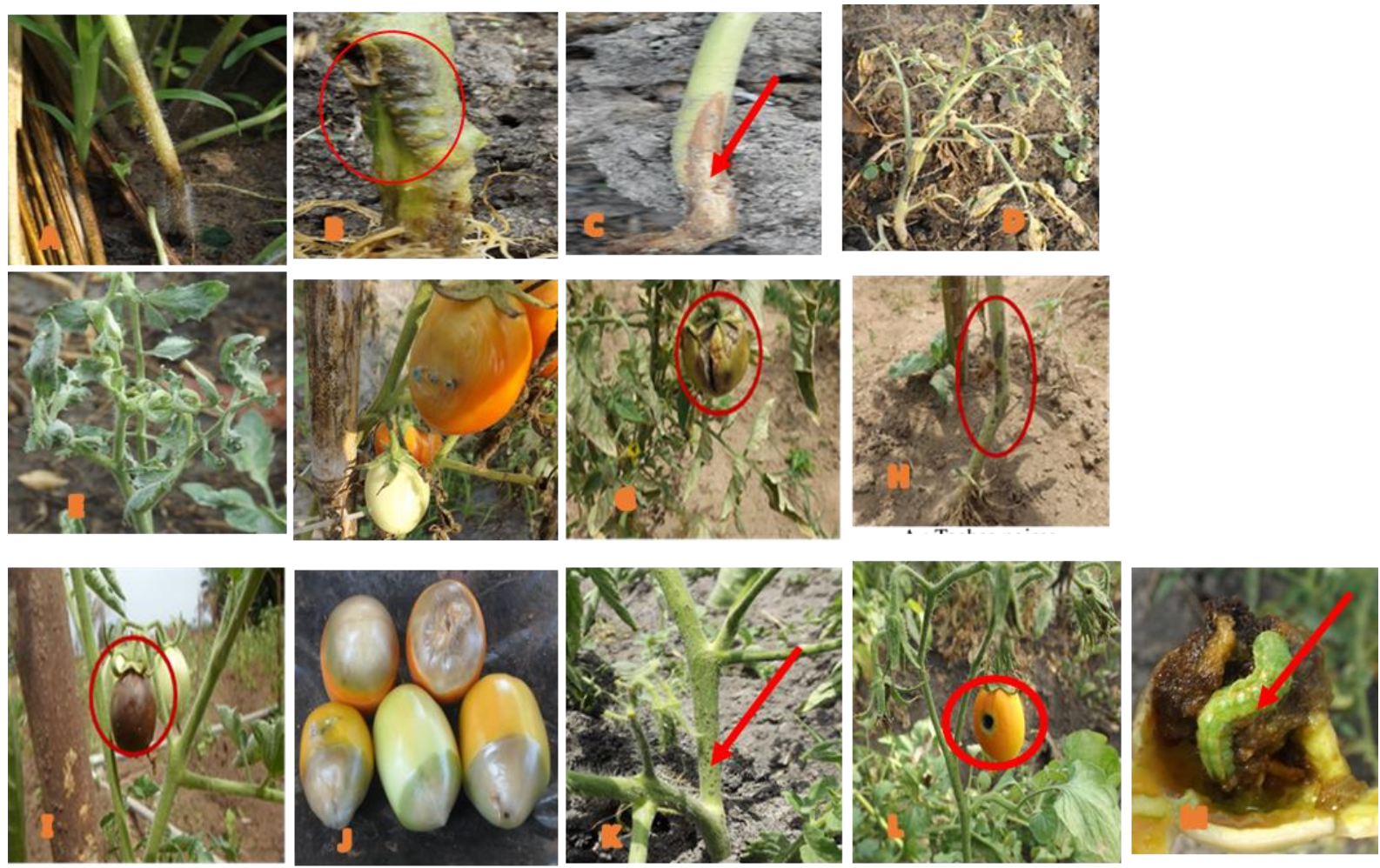

Figure 1. Major tomato diseases and pests in the locality of Daloa

A: Rot at the base of a young tomato plant in a nursery

B: black rot at the base of a tomato stem

C: Brown discoloration on one side of hydroponic tomato stem

D: Full wilt of a tomato plant

E: Tomato leaf curl

F: Tomato fruit soft rot

G: Tomato stem and branches showing long black spots sometimes zoned with a yellow center

$\mathrm{H}$ : Tiny black spots on tomato stem

I: Tomato fruit completely affected by brown rot

$\mathrm{J}$ : Tomato fruit apical necrosis

K: Radial Slot of Tomato

$\mathrm{L}$ : Caterpillars of the moth Helicoverpa armigera inside tomato

M: Tomato fruit with a hole caused by Helicoverpa armigera caterpillar 


\section{Discussion}

In this study we set ourselves the objective of listing the major tomato diseases and pests in the locality of Daloa. To this end, we followed for 12 months so as to cover the different seasons of Daloa, tomato cultivation in several production sites of the locality. However, the majority of producers (94\%) grow tomatoes during the rainy season from May mainly because of the availability of water during this period. This restriction pushed us to carry out a maximum monitoring of the crop during this study period. Thus, it was found that during this cultivation season, diseases were more abundant on tomato than pests. These results seem to be consistent with those of Mossler and Dunn (2009) according to which pests are less significant on crops during the rainy season compared to diseases that are more problematic during the same period. Soro et al (2015) explains the low presence of insects in the rainy season by their high mortality due to frequent heavy rains during that period. This situation could be at the root of the outbreaks observed in the dry season during certain production cycles for most crop pests (Soro 2010, Yeboue 2014). Nevertheless, the causes of pest and disease pressure on crops remain moisture, soil-borne diseases and climate change (Mossler and Dunn 2009). Landston and Eaker (2009) add warm temperatures and dry climates (mainly for insects, whose infestation is affected by rain) to this list as the main conditions favoring the establishment of pests in crops. Despite the influence of humid and hot climates on the severity of diseases and pests, $6 \%$ of farmers in Daloa grow tomatoes all year round.

Tomato cultivation in Daloa is concentrated in rural and peripheral areas (80\%) on small areas of less than 2 ha. Most of the producers have a low level of education which does not make easy their ability to identify and effectively control tomato pests and diseases. The main tomato diseases in Daloa are those caused by various fungi, bacteria and nematodes. The roots, leaves, stems and fruits are all susceptible to damage from these microorganisms ranging from loss of plant vigor to crop loss.

Among the fungi that parasitize tomato plants, the genera Pythium, Fusarium, Rhizoctonia and Colletotrichum are fungi that cause economically significant losses (Abdelkader 2012, Touati \& Amor-Chelihi 2016). These pathogens are the cause of seedling damping-off in nursery and tomato aerial organ rot. They usually infect germinating seeds, young seedlings, succulent tissues and cause their rot. Several selected tomato varieties introduced in Côte d'Ivoire might be sensitive. Among Causative agent, the genus Fusarium has also been more damaging in tomato hydroponic as well as on-soil cultivation. Fusarium can persist for many years due to the formation of chlamydospores or the development of hyphae on organic residues (Burgess et al., 1994). Fusarium is responsible for tomato leaf wilting and yellowing. If these diseases can be managed by means of chemical control, this is not the case for the disease most feared by producers in the locality of Daloa, namely bacterial wilt caused by Ralstonia solanacearum. Also called fire blight of the South, this bacterial blight causes significant yield losses (N'guessan et al., 2012). It is widespread in the regions of Côte d'Ivoire, but in Daloa its impact on tomato cultivation is such that many farmers in Daloa abandon tomato cultivation for the benefit of other less parasitized food crops.

Although cropping practices are recommended for tomato enemies, they are not accepted by farmers who prefer a chemical control method that would be more convincing (Holmer et al., 2001). However, the general finding that emerges is that the low level of education of producers correlated to a lack of technical supervision would not promote the proper use of phytosanitary products thus creating accidents in plantations and poisoning phenomena. Elizabeth and Zira (2009) reported that most vegetable producers received information on the popularization of plants from their neighbors or acquaintances. As a result, some producers use pesticides such as polytrine (Cypermethrin) recommended for cotton, posing a danger to consumers (Kanda et al 2013, Son et al., 2017). Moreover, the dosages are not always respected which might cause phytotoxicities (Shankara 2005, Blancard et al., 2012). This misuse of pesticides is a real danger to the health of the entire corporation and their families as well as the environment (Ton et al., 2000, Kanda et al., 2013). Among the pesticides, the families of Pyrethroids and Neonicotinoids remain the most used by producers against tomato pests. However, some authors have shown the resistance of Plutella xylostella, Helicoverpa armigera and Bemisia tabaci to the chemical family of Pyrethroids (Houndété et al., 2010, 
Gnankiné et al., 2013). These insects are the main tomato pests in the city and outskirt farms of Daloa. This is also observed in other countries of the subregion, particularly in Senegal and Benin, where these insects cause considerable damage to vegetables (Sow 2007, Ahouangninou 2013). Furthermore, these polyphagous insects are the main vectors of plant viral diseases such as leaf wilting or leaf curl (Urbino et al., 2005, Ouali N'goran et al., 2014). They transmit viruses through bites during sap removal, causing plant stunting or dwarfism (Messiaen et al., 1993).

\section{Conclusion}

At the end of our study, we note that tomato crop in the locality of Daloa is prone to disease and pest attacks that degrade its quality and reduce its yield. The health status of tomato crop highlights the omnipresence of root-knot nematodes, bacterial, viral diseases as well as an abundance of fungal diseases. The main pests observed are Helicoverpa armigera, Dysdercus sp., Bemisia tabaci and Zenocerus variegatus. This study provides a trail from which further studies could be conducted for mapping the most significant diseases in the region so as to better monitor and protect tomato cultivation.

\section{Acknowledgements}

Funding for This work was supported by the University of Jean Lorougnon Guedé (Daloa- Côte d"ivoire). The author is indebted to the anonymous referees whose guidance has significantly improved the quality and presentation of the article.

\section{References}

1. Abdelkader. F. (2012). Etude comparative de l'infection des sols par quelques champignons pathogènes en conditions de semis direct et de travail conventionnel. Diplôme de Magister en Sciences Agronomiques, Option : production Végétale et Agriculture de conservation. Université Ferhat Abbas Setif, Algérie, 89 p. Available : http://fac.umc.edu.dz/snv/faculte/biblio/mmf/2016/191.pdf (accessed 10/10/2017)

2. Ahouangninou. C. C. A. (2013). Durabilité de la production maraîchère au Sud-Bénin : un essai de l'approche écosystémique. Thèse de Doctorat de I'Université d'Abomey-Calavi, spécialité : Gestion de l'environnement, Bénin, 349 p.

3. Blancard, D., Lot, H.and Maisonneuve, B. (2003). Maladies des salades. Identifier, connaître et maîtriser. Paris, FRA : INRA Editions, 375 p.

4. Blancard, D., Vanhuffel, L., Chesneau, T. and Armand J-C. (2012). Inventaire des maladies et des bioagresseurs des cultures légumières de Mayotte. Rapport de mission, INRA, France, $25 \mathrm{p}$.

5. Burgess, L.W., Summerell, B. A., Bullock, S., Gott, K. P., and Backhouse, D. (1994). Laboratory Manual for Fusarium Research, 3rd ed. University of Sydney and Botanic Garden, Sydney, Australia.

6. Doumbouya, M., Koné, D., Fondio, L., SORO, S., Yatty, J. K. and AÏDARA, D. (2010). Caractérisation pathogénique de Sclerotium rolfsii Saccardo (Corticiaceae) sur 3 variétés de tomates et effet du milieu de culture sur le potentiel infectieux du champignon. Int. J. Biol. Chem. Sci. 4(4): 1294-1309, August 2010 .ISSN 1991-8631

7. Elizabeth, S. and Zira, D. (2009). Awareness and effectiveness of vegetable technology information packages by vegetable farmers in Adamawa State, Nigeria. J. Agr. Res. 4(2):65-70. 
8. Fondio, L., Djidji, H. A., N'gbesso F. P. M. and Daouda KONE; D. (2013). Evaluation de neuf variétés de tomate (Solanum Lycopersicum L.) par rapport au flétrissement bactérien et à la productivité dans le Sud de la Côte d'Ivoire. Int. J. Biol. Chem. Sci. 7(3): 1078-1086, June 2013

9. Gnakiné, O., Mouton, L., Savadogo, A., Martin, T., Sanon, A. and Dabire, R. K. (2013). Biotype status and resistance to neonicotionoids and carbosulfan in Bemissia tabaci (Hemiptera : Aleyrodidae) in Burkina Faso, West Africa. International Journal of pest Management, 59 (2) : 95-102.

10. Holmer, R. J., Janubas, L.G., Potutan, G.E. and Schnitzler, W. H. '(2001). Pest management strategies of urban and periurban vegetable growers in Cagayan de Oro City. 13thNOMCARRD Regional Symp. on R\&D Highlights, Farmers / Investors Forum and Media Conf., Dalwangan, Malaybalay City, Philippines, 9-11 Aug. 2001.

11. Houndété, T. A., Kétoh, G. K., Herma, O. S. A., Brévault, T., Glitho, I. A. and Martin, T. (2010). Insecticide resistance in field population of Bemissia tabaci (Hemiptera : Aleyrodidae) in West Africa. Pest Management Science, $66: 1181-1186$.

12. Hugh, P., Erl, S. and Owen, O. (2015). Guide d'identification des ravageurs des grandes cultures et des cultures fourragères et de leurs ennemis naturels et mesures de lutte applicables à l'Ouest Canadien. Agriculture et Agroalimentaire Canada et Prairie Pest Monitoring Network, gordongroup. ISBN 978-0660-23341-3, 160 p.

13. Jones, J. P. (1991). Early Blight in Compendium of Tomato Diseases. APS. Press. St. Paul, MN. 13-14 pp. (tomato plants are infected by a plethora of diseases)

14. Kanda, M., Djaneye-Boundjou, G., Wala, K., Gnandi, K., Batawila, K. and Sanni, A. (2013). Application des pesticides en agriculture maraîchère au Togo. VertigO - la revue électronique en Sciences de l'environement, 13 (1) : 1-17.

15. Landston, D. and Eaker, T. (2009). Disease control in the home vegetable garden. Cooperative extension, University of Georgia, Athens, Ga.

16. Messiaen, C. M., Blancard, D., Bouxel, F. and Lfon, R. (1993). Les maladies des plantes maraîchères.3ème ed. INRA, Paris, $77 \mathrm{p}$.

17. Mossler, M.A. and Dunn, E. (2009). Florida crop / pest management profile: Okra. Univ. of Florida, IFAS Ext. Publication, Gainesville, Fla.

18. N'Guessan, C. A., Abo, K., Fondio, L., Chiroleu, F., . Lebeau, A., Poussier, S.,. Wicker, E. and Koné D. (2012). So Near and Yet so Far: The Specific Case of Ralstonia solanacearum Populations from Côte d'Ivoire in Africa. Bacteriology. Vol. 102, No. 8, 2012. 733-740

19. Ouali-N'Goran, S.W.M., Yao, K. P., Kra, K. D., Kouassi, K. P. and Tano, Y. (2014). Évaluation de l'efficacité de l'insecticide Tricel 480 EC comparée à la Deltamétrine et à la Cyperméthrine contre les ravageurs du chou (Brassicacae L. ssp.) en milieu paysan dans la région de Yamoussoukro en Côte d'Ivoire. Afrique Science 10(1), 194- 207.

20. Sastry, M. N. L. and Hegde, R. K. (1989). Variability of Phytophthora species obtained from plantation of Karnataka. Indian Phytopath. 42(3): 421-425.

21. 21. Semal, J. and Lepoivre, P. (2003). Les maladies des plantes, Page 9-22. In phytopathologie. Lepoivre, P., Les presses agronomiques de Gembloux, De Boeck Université, Bruxelles. 
22. 22. Shankara, N., Van, L. J., De Goffau, M., Hilmi, M., Van, D. B. and Florijin, A. (2005). La culture de la tomate : Production, transformation et commercialisation. 5ème ed. fondation agromisa et CTA, Wageningen, $122 \mathrm{p}$.

23. 23. Son, D., Somda, I., Legreve, A. and Schiffers, B. (2017). Pratiques phytosanitaires des producteurs de tomates du Burkina Faso et risque pour la santé et l'environnement. Cah. Agric., $26: 25005$.

24. 24. Soro, S., Doumbouya, M., Koné, D. and Kouadio Y. J. (2008). Potentiel infectieux des sols de cultures de tomate (Lycopersicon esculentum Mill.) sous abri et incidence de l'âge de repiquage sur la vigueur des plants vis-à-vis de Pythium sp. à Songon-Dabou en Côte d'Ivoire. Tropicultura, 26(3): 173-178.

25. 25. Soro, S. (2009). Caractérisation agronomique et culture sous voile de variétés améliorées de tomate (Lycopersicon esculentum, Mill.) en Côte d'Ivoire. Thèse de Doctorat Unique, Université d'Abobo-Adjamé, Abidjan, Côte d'Ivoire, 156 p.

26. 26. Soro, S., Diallo, A. H., Doumbia, M., Dao, D. and Tano, Y. (2010). Inventaire des insectes de l'igname (Dioscorea spp) cas de Bouaké et Toumodi (Côte d'Ivoire). Journal of Animal \& Plant Sciences, 6 (3): 715-723.

27. 27. Soro, S., Yeboue N. L. and TRA BI C. S. (2015). Contribution de la culture de la tomate (Lycopersicon esculentum mill. Solanacée) dans la onservation de la Forêt des Marais Tanoe-Ehy (Côte d'Ivoire). Journal of Animal \&Plant Sciences, 2015. Vol.26, Issue 2: 4072-4080

28. 28. Srinivasan, R. (2010). Safer tomato production techniques: A field guide for soil fertilityand pest management. AVRDC Publication. 2010;92-9058-182-4.

29. 29. Sow, G. (2007). Efficacité comparée de trois insecticides (Biobit, Neem, Métofos) sur Plutella xylostella (Linné, 1758) (Lepidoptera: Yponomeutidae), principal ravageurdes Crucifères dans les Niayes de Dakar (Sénégal). DEA en Biologie Animale. Université Cheick Anta Diop (UCAD) de Dakar, Sénégal, $84 \mathrm{p}$.

30. 30. Ton, P., Tovigan, S.and Vodouhe, S. D. (2000). Intoxications et morts au Bénin par I'Endosulfan. In : Pesticides et alternatives. Bulletin de pesticides, Action Network Africa, №10-Avril 2000.

31. 31. Tonessia, D.C., Koffi, N. C., Soko, D. F., Kouassi, K. D., Soro, L., Soumahin, E.F., Akaffou, D. S., Kouadio, Y.J and AKE, S. (2018). Study of germination and health quality of cotton seed grow in the West Central Region of Côte d'Ivoire. Agriculture \& Veterinary Sciences (SJAVS); ISSN $2348-1854$

32. 32. Touati, R. and Amor-Chelihi, L. (2016). Isolement et identification des moisissures d'une zone aride. Diplôme de Master des Sciences de la Nature et de la Vie, Microbiologie, Option : Ecologie Microbienne. Université des Frères Mentouri Constantine, Algérie, 51 p. Available : fac.umc.edu.dz/snv/faculte/biblio/mmf/2016/191.pdf (accessed 10/10/2017)

33. 33. Urbino, C., Caruana, M. L., Pavis, C., La Fortune, D., Boissot, N. and Dintinger, J. (2005). Protection intégrée de la tomate contre les maladies à begomovirus. CIRAD Flhor, France, $10 \mathrm{p}$.

34. 34. Yeboue, N. L, Foua Bi, K. and Kehe, M (2002). Inventaire de l'entomofaune associé à la culture du gombo (Abelmoschus esculentusL.) en zone forestière de la Côte d'Ivoire. Agronomie Africaine (AISA), XIV (3) : 165-181.

35. 35. Yeboue, N. L, Soro, S. and Soro, D. (2014). Distribution of coreinae (Heteroptera Coreidae) in Côte-d'Ivoire. Journal of agriculture and biodiversity research, 3 (6): 68-77. 